\title{
Detection of alpha-thalassemia-1 Southeast Asian type using real-time gap-PCR with SYBR Green1 and high resolution melting analysis
}

\author{
Sakorn Pornprasert ${ }^{1}$, Arunee Phusua ${ }^{2}$, Sudjai Suanta ${ }^{2}$, Rattika Saetung ${ }^{2}$, Torpong Sanguansermsri ${ }^{2}$ \\ ${ }^{1}$ Department of Medical Technology, Faculty of Associated Medical Sciences, Chiang-Mai University, Chiang-Mai, Thailand; ${ }^{2}$ Division of \\ Hematology, Department of Pediatrics, Faculty of Medicine, Chiang-Mai University, Chiang-Mai, Thailand
}

\begin{abstract}
$\alpha$-Thalassemia-1 Southeast Asian (SEA) type is the most common genetic disorder in the Asian population. Couples who are both carriers have a $25 \%$ chance of conceiving Bart's hydrops fetalis. Therefore, results from carrier screening and prenatal diagnosis frequently need to be available rapidly. A rapid technique for diagnosis of $\alpha$-thalassemia-1 SEA type was implemented. The technique used is based on real-time gapPCR and high resolution melting (HRM) analysis of the amplified fragment using the Rotor-Gene $6000^{\mathrm{TM}}$. The DNA samples used for amplification were obtained from whole blood, cord blood, and chorionic villus sampling (CVS). With this method, the $\alpha$-thalassemia-1 SEA allele can be easily distinguished from wild type $\alpha$-globin gene allele. The real-time gap-PCR and HRM analysis offers additional benefits including minimal labor, rapid turnaround time, and a decreased risk of PCR carryover contamination. It is cost-effective and safe, does not require fluorescently labeled probe and hazardous chemicals. Moreover, it is accurate showing $100 \%$ concordance with conventional gap-PCR analysis.
\end{abstract}

Key words Real-time; gap-PCR; SYBR Green1; alpha-thalassemia-1; high resolution melting analysis

Correspondence Sakorn Pornprasert, Department of Medical Technology, Faculty of Associated Medical Sciences, Chiang-Mai University, 110 Intawaroros Road, Chiang Mai, Thailand, 50200. Tel: 66-53-945078; Fax: 66-53-946042; e-mail: sakornmi001@ yahoo.com

Accepted for publication 5 February 2008

doi:10.1111/j.1600-0609.2008.01055.x

$\alpha$-Thalassemia is one of the most serious genetically transmitted diseases creating health problems in many countries, with gene frequencies varying between $1 \%$ and $98 \%$ throughout the tropics and subtropics. More than $95 \%$ of recognized $\alpha$-thalassemia involved deletion of 1 or both $\alpha$-globin genes from chromosome 16p13.3 $(1,2)$. These gene deletions caused mild $\alpha$-thalassemia-2 and severe thalassemia-1, respectively. The most common type of thalassemia-1 in the Asian population is the Southeast Asian type (SEA) (3). Even thought carriers of the $\alpha$-thalassemia-1 with SEA type do not manifest any clinical symptoms, couples who are both carriers have a $25 \%$ chance of conceiving a homozygous fetus, which manifests as Bart's hydrops fetalis, the most severe thalassemic syndrome. All of these fetuses die either in utero or soon after birth (4-6). In addition, approximately $75 \%$ of mothers carrying fetuses with homozygous for the $\alpha$-thalassemia-1 SEA type will develop toxemia of pregnancy (7). An investigation of $\alpha$-thalassemia-1 SEA type is therefore essential for carrier couples and for prenatal diagnosis of fetus conceived by couples who are both carriers of this type of gene deletion.

The gap-PCR analysis currently used to diagnose $\alpha$ thalassemia-1 SEA type is based on multiplex amplification at the breakpoint area of thalassemia-1 with SEA type and the wide type $\alpha$-globin gene allele. The technique requires labor intensive, time-consuming, and post-PCR processing steps (8). In an effort to develop a more straightforward diagnostic test, quantitative realtime PCR with specific probes $(9,10)$ has been used for detection of $\alpha$-thalassemia-1 SEA type. Probe-based assays are generally used for multiplex real-time PCR analysis. However, they are relatively expensive. Realtime PCR with SYBR Green 1 followed by melting curve analysis has also been use to enhance the speed 
of $\alpha$-thalassemia-1 SEA detection $(11,12)$. However, this technique is not suitable for gap-PCR. Recently, a high resolution melting (HRM) analysis incorporating the fluorescent dye has been used for detecting heterozygous and homozygous sequence variants for genotyping and variation scanning (13-15). This approach is a closed system that does not require a fluorescently labeled probe or a separation step. In contrast to traditional melting curve analysis, HRM reliably detects single-base differences in homozygous and heterozygous sequence (16). This technique is cost-effective, has high sensitivity and specificity, rapid turnaround time, and decreases a risk of PCR carryover contamination.

In this study, we report a novel and powerful scheme combining real-time gap-PCR with SYBR Green1 and high resolution melting analysis for rapid detection of $\alpha$ thalassemia-1 SEA type.

\section{Materials and methods}

\section{DNA samples}

DNA was extracted from a hundred samples including 80 whole blood, 10 cord blood, and 10 chorionic villus sampling (CVS) using the Chelex method (Chelex 100 Resin, Sigma, CA, USA) (17). According to the thalassemia screening protocol, the genotype from each sample was firstly determined by the conventional gap-PCR analysis. This study was approved by the Ethics Committee of the Faculty of Associated Medical Sciences, Chiang-Mai University.

\section{Real-time gap-PCR with SYBR Green1 and HRM analysis}

DNA amplification was carried out in a $20 \mu \mathrm{L}$ reaction volume containing : $10 \mu \mathrm{L}$ of $2 \times$ SYBR Green 1 PCR master mix (Quantimix easy SYG kit, Biotools, Madrid, Spain) and $0.38 \mu \mathrm{M}$ of each primer with nucleotide sequences as shown in Table 1 and $7 \mu \mathrm{L}$ of DNA sample. The gap-PCR with SYBR Green1 was performed on Rotor-Gene 6000 ${ }^{\mathrm{TM}}$ (Corbett Research, Mortlake, New South Wales, Australia). The mixture was preheated at $95^{\circ} \mathrm{C}$ for $3 \mathrm{~min}$ and then the PCR was cycled 40 times at $95^{\circ} \mathrm{C}$ for $20 \mathrm{~s}, 60^{\circ} \mathrm{C}$ for $20 \mathrm{~s}$, and $72^{\circ} \mathrm{C}$ for $20 \mathrm{~s}$. The amplification cycles were followed by high resolution melting cycle from $85^{\circ} \mathrm{C}$ to $95^{\circ} \mathrm{C}$ at a rate of $0.1^{\circ} \mathrm{C}$ per
$2 \mathrm{~s}$. When the melting temperature (Tm) is reached, double stranded DNA is denatured and the SYBR Green 1 is released which cause a dramatic decrease in fluorescence intensity. The rate of this change was determined by plotting the derivative of the fluorescence relative to the temperature $(\mathrm{dF} / \mathrm{dT})$ vs. temperature by data analysis software of the real-time PCR instrument. The temperature at which a peak occurs on the plot corresponds to the Tm of the DNA duplex.

\section{Results}

In $\alpha$-thalassemia-1 SEA trait, two amplified fragments from the $\alpha$-thalassemia-1 SEA allele and from wild type $\alpha$-globin gene allele were generated. The amplified fragments from $\alpha$-thalassemia-1 SEA allele had the specific peak at $\mathrm{Tm}$ of $88 \pm 1^{\circ} \mathrm{C}$ whereas the amplified fragments from wild type $\alpha$-globin gene allele had the specific peak at $\mathrm{Tm}$ of $91 \pm 1^{\circ} \mathrm{C}$ (Fig. 1A-C). Only an amplified fragment from the $\alpha$-thalassemia-1 SEA allele with the specific peak at Tm of $88 \pm 1{ }^{\circ} \mathrm{C}$ was found in Bart's hydrops fetalis (Fig. 1B and C), while only an amplified fragment from the wild type $\alpha$-globin gene allele with the specific peak at $\mathrm{Tm}$ of $91 \pm 1^{\circ} \mathrm{C}$ was found in normal individual (Fig. 1A-C).

DNA samples extracted from cord blood of normal individual, thalassemia-1 SEA trait and Bart's hydrops fetalis showed similar specific peak heights as observed in those extracted from CVS (Fig. 1B and C, respectively). These specific peak heights were also found similarly in DNA samples extracted from whole blood of normal individual and thalassemia-1 SEA trait (Fig. 1A).

Moreover, the results of real-time gap-PCR with SYBR Green 1 and HRM analysis of a hundred assessed samples including 80 whole blood, 10 cord blood and 10 CVS were completely consistent with those of conventional gap-PCR analysis (Table 2).

\section{Discussion}

This study shows that the real-time gap-PCR with SYBR Green 1 and HRM analysis could facilitate rapid screening of $\alpha$-thalassemia-1 SEA type. It could assay the DNA samples processed from CVS that is of benefit for prenatal diagnosis of Bart's hydrops fetalis in the fetus and is offered to all couples who are both carriers of the $\alpha$-thalassemia-1 with SEA type allele. This technique

Table 1 Primer sequences used in real-time gap-PCR with SYBR Green 1 for detection of $\alpha$-thalassemia-1 SEA type

\begin{tabular}{llll}
\hline Primer & Sequence $\left(5^{\prime} \rightarrow 3^{\prime}\right)$ & $\begin{array}{l}\text { Product } \\
\text { length (bp) }\end{array}$ & $\begin{array}{l}\text { GenBank } \\
\text { accession no. }\end{array}$ \\
\hline Nal-Forward primer & AGA AGC TGA GTG ATG GGT CCG & - & Z84721 \\
Nall-Reverse primer & ACA AAC GCC CGT CCG ACT CAA & 196 & Z84721 \\
Nalll-Reverse primer & TGG ACT TAA GTG ATC CTC CTG CCC & 134 & Z69706 \\
\hline
\end{tabular}



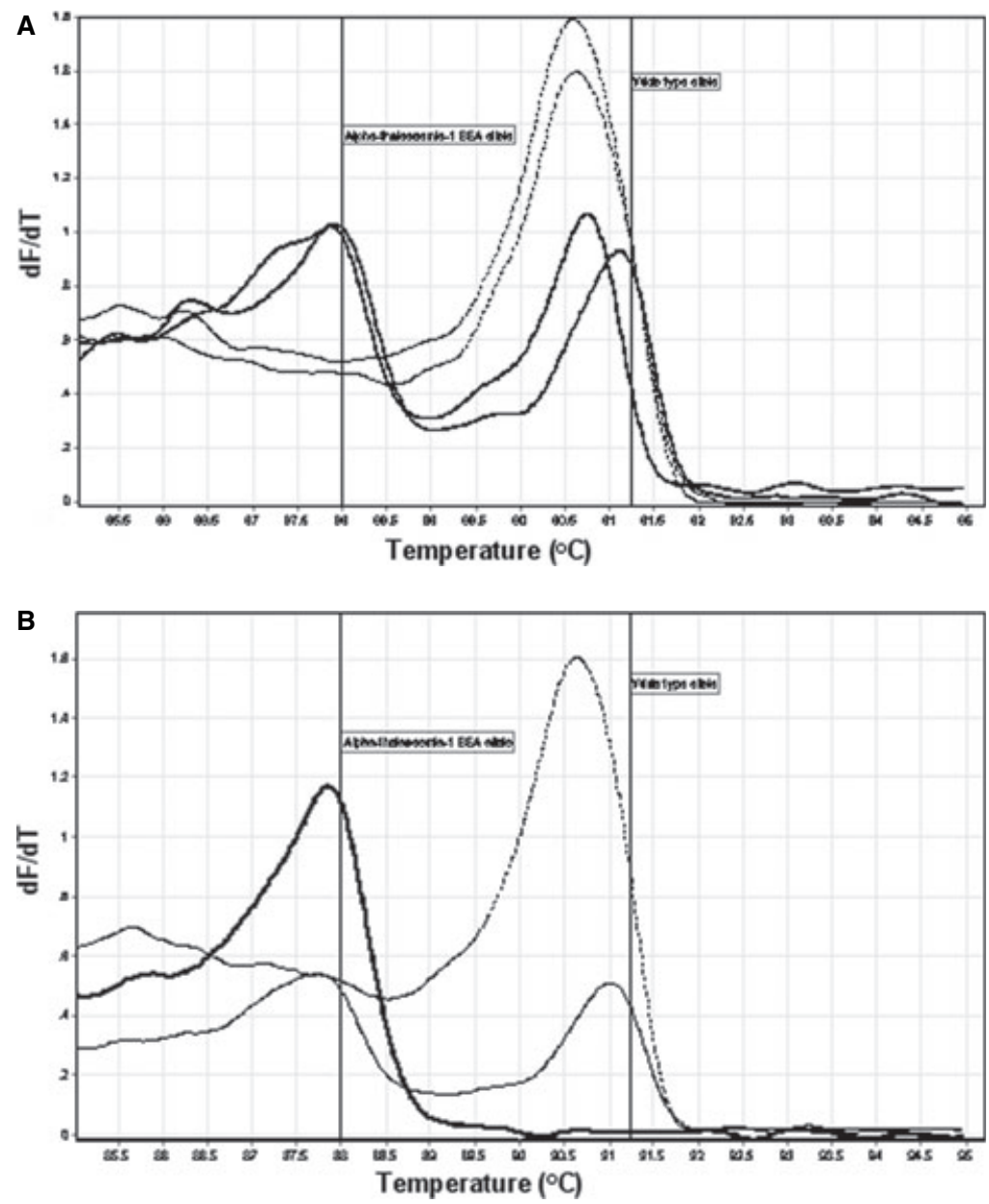

Figure 1 Dissociation curve analysis of thalassemia-1 SEA type. DNA samples were extracted from whole blood (A), cord blood (B), and chorionic villus sampling $(C)$ of normal individual $(. . . .$.$) , thalassemia-1 SEA trait (\longrightarrow)$ and Bart's hydrops fetalis

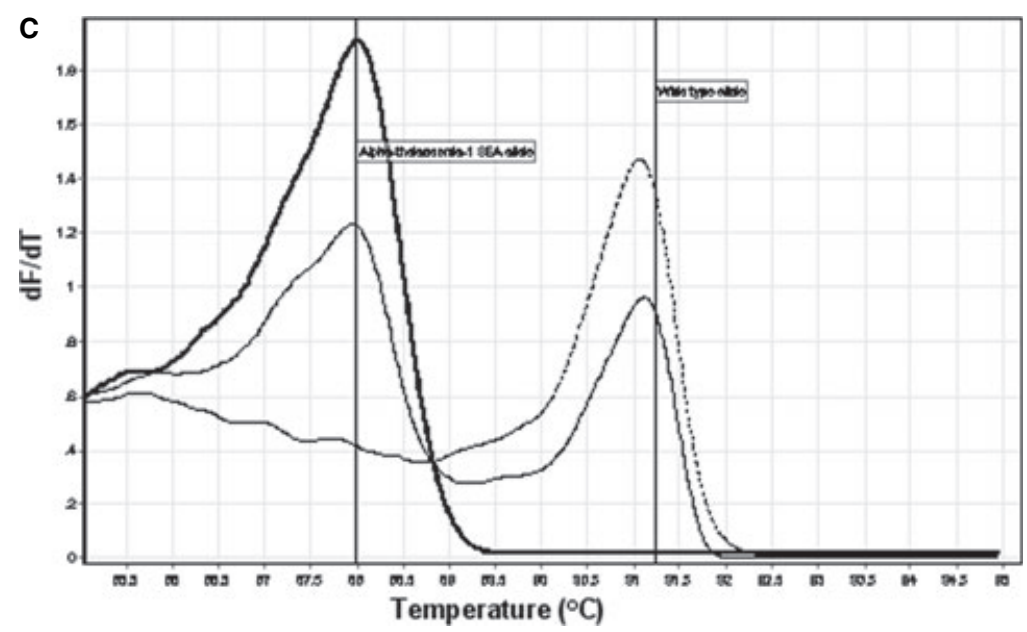

does not require fluorescently labeled probes or separation steps. It therefore offers additional benefits including minimal labor, rapid turnaround time, and decreased risk of PCR carryover contamination. The gap-SYBR Green1-PCR with HRM analysis for detection of $\alpha$-thalassemia-1 SEA can supply timely information. Such results from carrier screening frequently need to be avail- able rapidly, especially when couples present after establishment of a pregnancy (18).

Without HRM methodology, the real-time gap-PCR with SYBR Green1 and melting analysis had been performed for detection of $\alpha$-thalassemia-1 SEA type. By using primers with nucleotide sequence similar to those used in conventional gap-PCR, the melting curve analy- 
Table 2 The results of $\boldsymbol{\alpha}$-thalassemia SEA type of a hundred DNA samples

\begin{tabular}{|c|c|c|c|c|}
\hline \multirow[b]{2}{*}{ Specimen } & \multicolumn{2}{|c|}{ gap-PCR and HRM analysis } & \multirow{2}{*}{$\begin{array}{l}\text { Genotype } \\
\text { tested by } \\
\text { conventional } \\
\text { gap-PCR }\end{array}$} & \multirow[b]{2}{*}{$\begin{array}{l}\text { Case } \\
\text { number }\end{array}$} \\
\hline & $\begin{array}{l}134 \mathrm{bp} \\
\operatorname{Tm} 88 \pm 1^{\circ} \mathrm{C}\end{array}$ & $\begin{array}{l}196 \mathrm{bp} \\
\operatorname{Tm} 91 \pm 1^{\circ} \mathrm{C}\end{array}$ & & \\
\hline \multirow{2}{*}{$\begin{array}{l}\text { Whole } \\
\text { blood } \\
(n=80)\end{array}$} & - & + & $\alpha \alpha / \alpha \alpha$ & 73 \\
\hline & + & + & SEA $/ \alpha \alpha$ & 7 \\
\hline \multirow{3}{*}{$\begin{array}{l}\text { Cord } \\
\text { blood } \\
(n=10)\end{array}$} & - & + & $\alpha \alpha / \alpha \alpha$ & 3 \\
\hline & + & + & SEA $/ \alpha \alpha$ & 4 \\
\hline & + & - & _SEA/_SEA & 3 \\
\hline \multirow{3}{*}{$\begin{array}{l}\text { CVS } \\
\qquad(n=10)\end{array}$} & - & + & $\alpha \alpha / \alpha \alpha$ & 3 \\
\hline & + & + & _SEA/ $\alpha \alpha$ & 3 \\
\hline & + & - & _SEA/_SEA & 4 \\
\hline
\end{tabular}

sis was clearly differentiated between Bart's hydrops fetalis and normal individuals. However, the melting curves of the heterozygous were not clearly distinguishable from those of normal subjects (19). Based on rapid detection and appropriation for HRM analysis, three oligonucleotide primers were designed for amplifying small DNA fragments, 134 and $196 \mathrm{bp}$, from the $\alpha$-thalassemia-1 SEA allele and wild type $\alpha$-globin gene allele, respectively. After a high resolution melting temperature analysis, peak heights of Tm were observed specifically in each fragment. These specific peak heights could facilitate rapid screening of heterozygous and homozygous $\alpha$-thalassemia-1 of SEA type.

A previous study suggested that SYBR Green 1 was not suitable for HRM analysis since it can only be used at non-saturating concentration. Therefore, SYBR Green 1 that dissociated from DNA during melting can re-intercalate into regions of unmelted double stranded DNA (20). This phenomenon of fluorescence dye redistribution can mask the small differences in melting behaviour $(21,22)$. However, the re-intercalation of SYBR Green1 did not affect our study. Because the gap-PCR with SYBR Green 1 and HRM analysis was set up for detecting of $\alpha$-globin gene deletion and is unlike the analysis of single gene mutation, the discrimination of amplicons with sufficiently different Tm values can be provided in the present study.

In conclusion, our results indicated the real-time gapPCR with SYBR Green1 and HRM analysis for diagnosis of $\alpha$-thalassemia-1 SEA type is much safer than conventional gap-PCR method because it does not use hazardous chemicals such as acrylamide and ethidium bromide. This technique is cost-effective, uses minimal labor, has rapid turnaround time, and decreases risk of PCR carryover contamination. The real-time gap-PCR with SYBR Green 1 may be one alternative technology available for routine clinical diagnosis of $\alpha$-thalassemia- 1 with the SEA type.

\section{Acknowledgements}

The authors thank technicians in the Division of Hematology, Department of Pediatrics, Faculty of Medicine, Chiang-Mai University, Chiang-Mai, Thailand for their help and assistance. We are grateful to Gerald W. Rock for editing the manuscript.

This study was supported by grants from the Department of Health Ministry of Public Health, Thailand.

\section{References}

1. Higgs DR, Vickers MA, Wilkie AO, Pretorius IM, Jarman AP, Weatherall DJ. A review of the molecular genetics of the human alpha-globin gene cluster. Blood 1989;73:1081-104.

2. Kazazian HH, Jr. The thalassemia syndromes: molecular basis and prenatal diagnosis in 1990. Semin Hematol 1990;27:209-28.

3. Fucharoen G, Fucharoen S, Wanhakit C, Srithong W. Molecular basis of alpha (0)-thalassemia in northeast of Thailand. Southeast Asian J Trop Med Public Health 1995;26(Suppl 1):249-51.

4. Liang ST, Wong VC, So WW, Ma HK, Chan V, Todd D. Homozygous alpha-thalassaemia: clinical presentation, diagnosis and management. A review of 46 cases. $\mathrm{Br} \mathrm{J}$ Obstet Gynaecol 1985;92:680-4.

5. Ko TM, Hsieh FJ, Hsu PM, Lee TY. Molecular characterization of severe alpha-thalassemias causing hydrops fetalis in Taiwan. Am J Med Genet 1991;39:317-20.

6. Thumasathit B, Nondasuta A, Silpisornkosol S, Lousuebsakul B, Unchalipongse P, Mangkornkanok M. Hydrops fetalis associated with Bart's hemoglobin in northern Thailand. J Pediatr 1968;73:132-8.

7. Torcharus K, Sriphaisal T, Krutvecho T, Ketupanya A, Vuthiwong C, Suwanasophon C, Noonai A. Prenatal diagnosis of Hb Bart's hydrops fetalis by PCR technique: Pramongkutklao experience. Southeast Asian J Trop Med Public Health 1995;26(Suppl 1):287-90.

8. Winichagoon P, Fucharoen S, Kanokpongsakdi S, Fukumaki Y. Detection of alpha-thalassemia-1 (Southeast Asian type) and its application for prenatal diagnosis. Clin Genet 1995;47:318-20.

9. Chan V, Yip B, Lam YH, Tse HY, Wong HS, Chan TK. Quantitative polymerase chain reaction for the rapid prenatal diagnosis of homozygous alpha-thalassaemia (Hb Barts hydrops fetalis). Br J Haematol 2001;115:3416.

10. Sun CF, Lee $\mathrm{CH}$, Cheng $\mathrm{SW}$, Lin $\mathrm{MH}, \mathrm{Wu}$ TL, Tsao $\mathrm{KC}$, Chiu DT, Liou JD, Chu DC. Real-time quantitative PCR analysis for alpha-thalassemia-1 of Southeast Asian type deletion in Taiwan. Clin Genet 2001;60:305-9.

11. Liu J, Yan M, Wang Z, Wang L, Zhou Y, Xiao B. Molecular diagnosis of alpha-thalassemia by combining real-time PCR with SYBR Green 1 and dissociation curve analysis. Transl Res 2006;148:6-12. 
12. Yan M, Wang LR, Wang ZY, Zhou Y, Liang Y, Xiao B, Liu JZ. Detection of alpha thalassemia using real-time PCR and dissociation curve analysis. Zhonghua Yi Xue Yi Chuan Xue Za Zhi 2007;24:192-5.

13. Graham R, Liew M, Meadows C, Lyon E, Wittwer CT. Distinguishing different DNA heterozygotes by highresolution melting. Clin Chem 2005;51:1295-8.

14. Liew M, Pryor R, Palais R, Meadows C, Erali M, Lyon E, Wittwer C. Genotyping of single-nucleotide polymorphisms by high-resolution melting of small amplicons. Clin Chem 2004;50:1156-64.

15. Reed GH, Wittwer CT. Sensitivity and specificity of single-nucleotide polymorphism scanning by high-resolution melting analysis. Clin Chem 2004;50:174854.

16. Zhou L, Wang L, Palais R, Pryor R, Wittwer CT. High-resolution DNA melting analysis for simultaneous mutation scanning and genotyping in solution. Clin Chem 2005;51:1770-7.

17. Walsh PS, Metzger DA, Higuchi R. Chelex 100 as a medium for simple extraction of DNA for PCR-based typing from forensic material. Biotechniques 1991;10:50613.
18. Fucharoen S, Winichagoon P, Thonglairuam V, Siriboon W, Sae-Ngow B. Laboratory diagnosis for thalassemia. Ann Acad Med Singapore 1989;18:424-30.

19. Pornprasert S, Sukunthamala K, Sacome J, Phusua A, Saetang R, Sanguansermsri T, Leechanachai P. Analysis of real-time SYBR-PCR cycle threshold for diagnosis of $\alpha$-thalassemia-1 Southeast Asian type deletion: application to carrier screening and prenatal diagnosis of Bart's hydrops fetalis. Hemoblobin 2008; In press.

20. Giglio S, Monis PT, Saint CP. Demonstration of preferential binding of SYBR Green I to specific DNA fragments in real-time multiplex PCR. Nucleic Acids Res 2003;31:e136.

21. Herrmann MG, Durtschi JD, Bromley LK, Wittwer CT, Voelkerding KV. Amplicon DNA melting analysis for mutation scanning and genotyping: cross-platform comparison of instruments and dyes. Clin Chem 2006;52:494 503.

22. Krypuy M, Newnham GM, Thomas DM, Conron M, Dobrovic A. High resolution melting analysis for the rapid and sensitive detection of mutations in clinical samples: KRAS codon 12 and 13 mutations in non-small cell lung cancer. BMC Cancer 2006;6:295. 